\title{
Chapter 4 \\ The Netherlands: Focus on Excellence, Honors Programs All Around
}

\subsection{Education System}

The Netherlands (...) has perhaps the most unified, consistent, and self-conscious array of honors programs and research projects about honors based on the U.S. model. (Long 2012, p. 9)

The attitude towards excellence changed quickly in Dutch society over the last 20 years. 'Until recently in the Netherlands, special programs to support weaker students were generally accepted, whereas "high potential programs" (honors) were considered inappropriate in a democracy where all students should be treated equally - a stance that still prevails in many European countries' (Wolfensberger 2012, p. 16; see also Wolfensberger et al. 2012a, p. 149). But now, excellence in education is named a priority by the ministry of Education and money is set aside for it. The development of honors programs at higher education institutions started in 1993, but accelerated in the early 2000s. As inspiration for the development of programs was sought in the United States, the term 'honors program' was imported and has since been widely used for the extra educational offers made to excellent students in higher education in the Netherlands. In 2004, the ministry of Education established a temporary commission called Ruim baan voor talent (make room for talent), which provided small subsidies to experimental differentiation projects at HEIs, including honors programs, until 2007. ${ }^{1}$ A major incentive to the development of these programs came in 2008, when more government subsidies through the national Sirius Programme became available. By now, most HEIs in the Netherlands have honors programs.

The attention for excellence in higher education is embedded in an education system where focus on excellence has significantly increased over the last few years (Boxes 4.1 and 4.2). Many provisions for excellent students are already in place in primary and secondary education and the government strongly supports further development.

\footnotetext{
${ }^{1}$ See Commissie Ruim baan voor Talent 2007 for the commission's final report.
} 


\section{Box 4.1: The Netherlands - The Basics}

- 16.8 million inhabitants

- Capital: Amsterdam

- Constitutional monarchy

- 12 provinces

- Social-democratic/liberal coalition in power

\section{Box 4.2: Education in the Netherlands}

- Free until age 18

- Compulsory from age 5-18 or until basic qualification is obtained

- System of public schools, religious schools and schools based on an educational philosophy

- Eight-grade primary school

- Differentiation after primary school (age 12) in three main types of secondary schools

- Higher education admission with secondary education diploma

- Ministry of Education, Culture and Science responsible for all levels of education

An extensive array of approaches to education, seen through a wide diversity of schools, defines the Dutch education system. This system rests on the principle of free school choice for parents. ${ }^{2}$ Public schools, on the one hand, and special schools based on religion or educational philosophy, on the other hand, are all financed by the government. In theory, special schools can reject pupils whose parents do not agree with the basic principles of the school, but this rarely happens. In fact, around $70 \%$ of all pupils attend special schools (CBS Statline 2014) ${ }^{3}$ and differences between special schools and public schools may be very limited.

While compulsory education starts at the age of five, almost all children enter the eight-grade primary school (basisschool) at age four. Differentiation occurs early. At the end of primary school, around age 12, pupils choose one of three options: pre-vocational secondary education $\left(v m b o, 4\right.$ years $\left.^{4}\right)$, senior general secondary

\footnotetext{
${ }^{2}$ This has been subject of much debate in the early twentieth century and subsequently the right of free school choice was included in article 23 of the Dutch constitution.

${ }^{3}$ Of all primary school children, over $69 \%$ attend special schools. In secondary education the number is even higher at $74 \%$.

${ }^{4}$ There are different types of vmbo education and exams can be taken at different levels. A vmbo diploma is not considered a 'starting qualification' to enter the labor market. Vmbo graduates under the age of 18 are required to continue their studies in vocational education courses, or at the havo.
} 
education (havo, 5 years) or pre university education (vwo, 6 years). Selection occurs with the advice of the teacher as main determinant, although a national test (CITO-toets) taken by most children ${ }^{5}$ also plays a large role.

While in secondary school, pupils can move between the three school types. Often this can be easily facilitated, as many schools offer all three levels of education in the same building. It is also possible to for example move to havo after passing a vmbo final exam, although extra requirements for admittance to the havo may be set by the individual school. National exams are taken at every level of secondary education in the last year. The structure of the Dutch education system is summarized in Fig. 4.1.

There have been a lot of excellence initiatives at the primary and secondary school levels from the 1980s (See Persson et al. 2000, p. 716-717 for some early initiatives). ${ }^{6}$ It is impossible to name them all in the short space available here. Generally speaking, many initiatives at these levels have moved from experimental status to a more permanent, institutionalized status, especially since the government made excellent education one of its official priorities in 2012 (Rijksoverheid 2012). Then, the government asked the Platform Bèta Techniek (also home of the Sirius Programme ${ }^{7}$ ) to write reports about the current situation and make recommendations for policy change. Think tanks were established, which published reports for primary education (Platform Bèta Techniek 2014) and secondary education (Platform Bèta Techniek 2013). In early 2014, this led to an action plan from the ministry, focusing on primary and secondary education (see Sect. 4.3).

Beyond national support, initiatives to make provisions for excellent students occur on the local level where schools themselves create distinctive initiatives. Some examples include:

- primary and secondary schools which focus especially on gifted and talented children ${ }^{8}$

- a primary school called 'Het Talent' works with age independent groups, where children receive education tailored to their level in content and in pace'; and

- a secondary school is experimenting with a 'sprint class', where pupils can finish their secondary school in a year less than usual. ${ }^{10}$

Sometimes local initiatives can lead to nationwide programs, for example in the case of the association of gymnasia. Local gymnasia developed programs for their best pupils, which have now evolved into an honors program offered to all member

\footnotetext{
${ }^{5}$ From the school year 2014/2015, taking the national test will be obligatory for all schools.

${ }^{6}$ Gifted education in its early years was mainly promoted by the Center for the Study of Giftedness at the Radboud University in Nijmegen, then headed by professor Franz Mönks.

${ }^{7}$ See Sect. 4.2 for more details.

${ }^{8}$ For example Leonardo schools, see www.leonardo-onderwijs.nl.

${ }^{9}$ See www.het-talent.nl.

${ }^{10}$ See www.pallasathenecollege.nl/nieuwe-leerling/bijzondere-programmas
} 


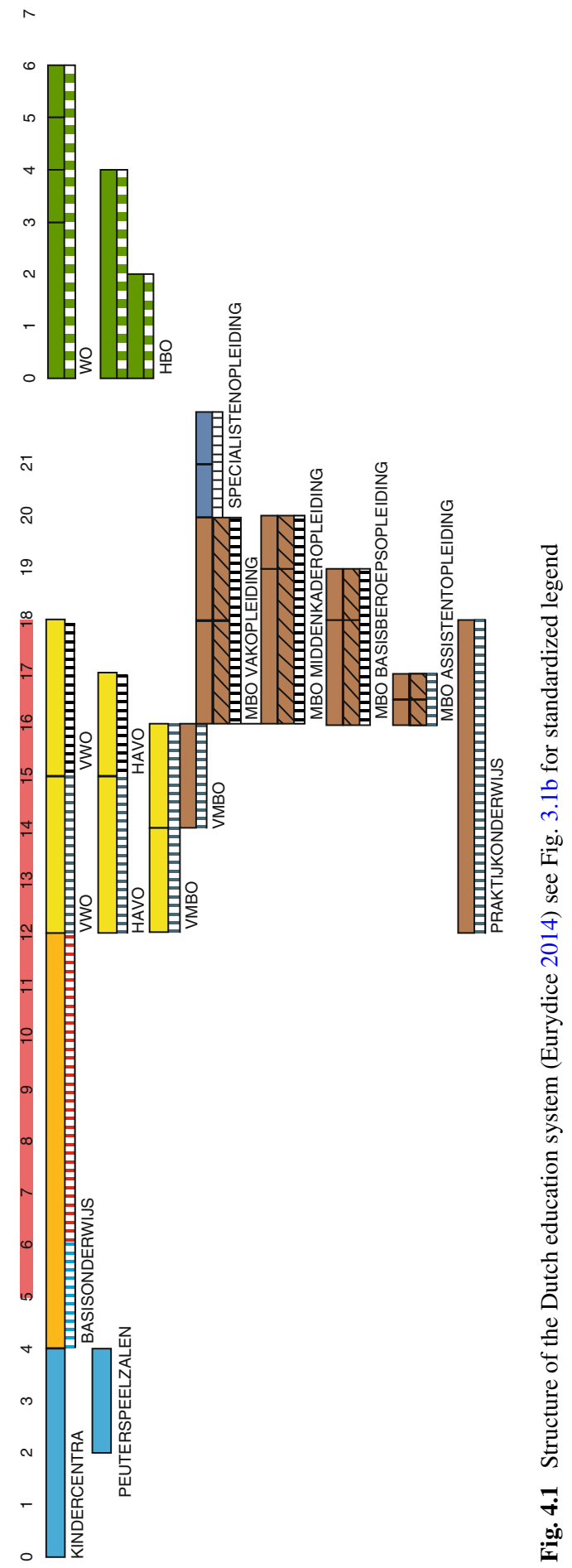


gymnasia through the association. ${ }^{11}$ Other initiatives for excellent pupils include national Olympiads in different subjects, which often include creative elements.

Nationwide, the government initiated a program in 2012, in which primary and secondary schools can officially be designated an 'excellente school' (excellent school), as inspired by a German example. For this purpose, excellence is viewed in various ways, including education results on different terrains and a school's own 'excellence policy', but also the way the school manages the educational process and the way the school handles specific circumstances in its environment.

Schools register themselves and a jury advises the minister if the school deserves the designation. If awarded, schools receive a plaque to hang at their door. In early 2014, 76 schools were awarded excellent status. ${ }^{12}$ In its annual report to parliament, the jury of the excellent schools concluded that these schools serve as examples for other schools; enthusiasm for the program grows annually (Ministerie van Onderwijs, Cultuur en Wetenschap 2014).

Primary and secondary schools can officially be designated 'excellent school'

A majority of universities in the Netherlands offer enrichment programs for talented secondary school students (see Sirius expertcommissie 2014 ${ }^{13}$ ). Junior College Utrecht (2014) provides a well-known example. Established in 2004, Junior College is a collaboration between Utrecht University and 27 secondary schools. It offers enrichment programs in science \& mathematics for talented and motivated 12- to 18- year old high school students (grades 7-12) in an academic environment. High school students who successfully finish the program in grade 11 and 12 receive a certificate that allows them to enter honours courses in the first year of the science bachelor programs. The Junior College applies a school-campus model: enrichment activities at the university campus are embedded in differentiated and challenging excellence programs run by the schools themselves. In this way, Junior College aims to contribute to the development of a culture of excellence at its partner schools. ${ }^{14}$

Dutch 15-year-olds generally score quite well in the 2012 PISA report. However, the number of students scoring excellent overall is below OECD average (Kordes et al. 2013, p. 84). This result provides an extra incentive to invest in excellence programs.

\footnotetext{
${ }^{11}$ See www.gymnasia.nl/uploads/files/conferenties-overige/HPG_de_basis.pdf

${ }^{12} \mathrm{See}$ www.rijksoverheid.nl/onderwerpen/predicaat-excellente-scholen/excellente-scholen and www.excellentescholen.nl

${ }^{13}$ At least five universities do this: Utrecht University, Leiden University, Radboud University Nijmegen, Maastricht University and University of Groningen. Hanze University of Applied Sciences Groningen also runs a similar program.

${ }^{14}$ The Junior College has attracted a lot of attention from different countries and is often referred to in international literature, such as Hermann et al. 2011, p. 65.
} 
Two main types of HEIs exist in the Netherlands (see Box 4.3), research universities and universities of applied sciences (hogescholen or hbo). Access to higher education is relatively open. A senior general secondary education (havo) diploma serves as a general entrance ticket to the universities of applied sciences, while the pre university education ( $v w o$ ) diploma grants university access. HEIs can demand that students pass secondary school exams in certain subjects to be admitted to certain majors. Also, some majors which are very popular and/or expensive for the government, use a restrictive admissions process (numerus fixus). This is for example the case for medicine, veterinary sciences and physiotherapy. Admission is currently handled in a complicated lottery system, in which good exam marks improve a student's chances of acceptance. ${ }^{15}$ The government intends to change this system by the study year 2017-2018. In the new system, HEIs can select students for the numerus fixus study programs themselves, based on different criteria, such as secondary school exam grades, personality and motivation (Rijksoverheid 2014b). In addition, a new system requiring a form of 'matching' between the student and the HEI is being implemented at various HEIs. This is used to couple students to the study path matching their talent best, with the additional goal of lowering retention rates in the first year. Some HEIs, such as Utrecht University, use this matching process to identify possible participants in honors programs.

\section{Box 4.3: Dutch Higher Education Landscape}

- 14 universities -10 general, 3 technical, 1 Open University

- 37 universities of applied sciences

- Over 70 accredited 'legal entities providing higher education'

There are 14 government-supported research universities in the Netherlands, all of which are member of the national network VSNU. Three are specialized technical universities and one, the Open University, provides distance learning. University education in the Netherlands has a long tradition, with four institutions dating back to the sixteenth and seventeenth centuries. ${ }^{16}$ The Dutch universities also have a good reputation internationally and score well in rankings. Almost all universities make it into the top-500 on the Shanghai list (ARWU 2013). ${ }^{17}$

\footnotetext{
${ }^{15}$ There are both national and institution-based studies with restricted student numbers, known as numerus fixus. Students with very high exam marks are guaranteed a place. This system applies to studies such as medicine. See Eurydice 2014, chapter 7.2 for more details.

${ }^{16}$ These are the universities of Amsterdam (1632), Leiden (1575), Utrecht (1636) and Groningen (1614).

${ }^{17}$ Twelve Dutch universities are on both the Shanghai List (ARWU 2013) and the Times List (Times Higher Education World University Ranking 2014). Utrecht, Leiden and Groningen score
} 
Apart from the research universities, a large number of universities of applied sciences (hogescholen) exists. Some of these are very large institutions, offering a multitude of educational options at different locations, while others are small and focused on one or a few disciplines. Small private schools can also call themselves "university of applied science", and the exact number of institutions can change quickly. However, all government-funded institutions are members of the national network Vereniging Hogescholen, which in September 2014 claimed 37 member institutions.

We have restricted our search for honors education to the research universities and universities of applied sciences.

Additionally, quite a large number of small private universities, business schools, specialized universities of applied sciences and art institutions offer higher education. In many cases, special admission criteria apply to these institutions, which are officially referred to as 'legal entities providing higher education'. The Netherlands provides free primary and secondary education up to the age of 18. A mandatory annual fee needs to be paid to study at a university or university of applied sciences. The tuition fee is $€ 1906$ for $2014 / 2015 .{ }^{18}$ For the moment, most students are entitled to a small monthly government grant to finance part of their studies, but this is subject to change. The government has introduced new legislation implying that from the study year 2015-2016, new students can only apply for a government loan to finance their studies and no longer for a grant.

\subsection{Culture and Policy Towards Excellence}

Wanting to excel in your studies is no longer an individual hobby, but an institutionalized possibility. (Wolfensberger and Pilot 2014, own translation)

Traditionally, the Netherlands has a culture of egalitarianism in education. Selectivity, competition, and differentiation in tuition are still new and unusual elements in the Dutch educational system, which has an emphasis on broad educational participation without entrance selection (Wolfensberger et al. 2012a, p. 150). Historically, the common belief held that gifted students 'will learn anyway and do not need any additional aid or guidance' (De Boer et al. 2013, p. 134). ${ }^{19}$ A culture of inclusion prevailed: while attempts were made to help less talented students keep pace with the basic curriculum, the facilities to encourage high-potential students to achieve excellence were insufficient.

\footnotetext{
in the top 100 on both lists. On the Times List, Amsterdam, Rotterdam, Delft, Wageningen and Maastricht are also in the top 100.

${ }^{18}$ Lower amounts apply for tertiary vocational education. Much higher fees can apply to students following extra studies and/or students from abroad. In addition, residential university colleges can charge higher tuition fees and additional campus fees.

${ }^{19}$ The article by De Boer et al. also provides a more detailed overview of the policy development regarding gifted education in the Netherlands in general.
} 
Various inspections and accreditation authorities guarantee that all educational institutions offer a good basic level curriculum, accessible to all students. Nonetheless, a relatively large number of students do not feel sufficiently inspired or challenged. In a 2014 report, a quarter of all secondary school pupils indicated that they are often or even always bored because their curriculum is too easy. Among the pupils who count themselves among the top $20 \%$ performers of their class, this percentage is $56 \%$ (Rijksoverheid 2014a, p. 4). ${ }^{20}$

In recent years, a shift in Dutch policy occurred. Due to the emphasis on the knowledge economy, the importance of fostering and promoting talent has gained recognition. Special provisions for talented and gifted children in primary and secondary schools are now widespread and different national networks and programs exist to support such efforts (Box 4.4). ${ }^{21}$

\section{Box 4.4: Local Terminology}

The word 'honors/honours' is widely used in higher education in the Netherlands. Other terms to refer to (programs for) gifted and talented children and students include:

- hoogbegaafd (highly gifted)

- talentvolle studenten (talented students)

- leervoorsprong ('ahead in learning')

- excellente studenten (excellent students)

By law, HEIs are allowed to select students for honors tracks according to their own procedures. ${ }^{22}$ The first honors programs in higher education started in 1993 (Wolfensberger et al. 2012a, p. 149) and large-scale development has been influenced by the Bologna Process. The Netherlands were relatively quick to adopt the bachelor/master system, and the new structure was in place for almost all new students by 2002. From then on, all universities have started to invest in excellence programs for ambitious and talented students, for various reasons (VSNU 2013). ${ }^{23}$ A more recent phenomenon is the development of honors programs at the universities of applied sciences. They followed the development at the universities and saw the number of programs increase 'from almost zero in 2004 to about 40 in 2010' (Wolfensberger et al. 2012a, p. 154).

In 2008, efforts were given an enormous impulse, when the Ministry of Education, Culture and Science established the Sirius Programme as an official initiative to

\footnotetext{
${ }^{20}$ Source is a report from research company Intomart, which was ordered by the ministry of Education, Culture and Science.

${ }^{21}$ The main part of this paragraph is taken from Sirius Programma 2014b.

${ }^{22}$ See Article $7.9 \mathrm{~b}$ of the 'Wet op het hoger onderwijs en wetenschappelijk onderzoek' (Law on higher education and scientific research).

${ }^{23}$ The reasons to develop programs have been discussed in part I of this study.
} 
promote excellence in higher education. The ministry invited all HEIs to submit a plan for the promotion of excellence, either independently or in collaboration with other institutions. The largest portion of the Sirius budget has been earmarked for the bachelor's program that was launched in 2008 (€48.8 million). The master program, with a budget of $€ 12.2$ million, started in the spring of 2010 . These funds provide the first incentive aiming at inspiring the top $5 \%$ of the students to achieve excellence. The Sirius Programme has a double focus: first, each institutions' goals, vision for the whole institution and the performances they wish to achieve (including the feasibility of those performance targets), and second, the learning function of the program as a whole (the sharing of knowledge so that Sirius institutes can learn from each other's experiences). With these points as the framework, Sirius aims to build up a community of participating and interested institutions oriented towards the gathering and sharing of knowledge. In this way, post-secondary institutions can learn both from themselves and from others. Five institutions commenced implementation in their bachelor programmes in the fall of 2008. In 2009, 14 others followed, and in 2010 six universities started to implement honors programs in the master tracks (Box 4.5). ${ }^{24}$

\section{Box 4.5: Key Players in Excellence}

The following institutions are among the most important players in the field of talent and excellence in higher education:

- The ministry of Education, Culture and Science

- The Platform Bèta Techniek, a government-supported independent body running many programs, including the Sirius Programme for higher education

- The Association of Universities (VSNU)

- The Association of Universities of Applied Sciences (Vereniging Hogescholen)

- Research universities, especially Utrecht, Leiden and Amsterdam

- Research Centre for Talent Development in Higher Education and Society at Hanze University of Applied Sciences Groningen

The honors programs and the more general theme of 'excellence in education' have also been the subject of a lot of research in the Netherlands. Founded by prof. Franz Mönks in 1988, the Center for the Study of Giftedness (CBO) at Radboud University Nijmegen has initiated important research on excellence and still leads this field, especially with regard to pupils in primary and secondary education. CBO also offers a 2-year post-academic teacher education program leading to a qualification as 'ECHA-Specialist in Gifted Education'.

${ }^{24}$ The main part of this paragraph is a slight adaptation of a paragraph from Sirius Programma 2014b. 
At many other universities and universities of applied sciences, specialists conduct research about talent development and excellence in education. For example, Van Eijl and Pilot are working from Utrecht University and have initiated a lot of (early) research on honors programs in the Netherlands (see for example Van Eijl et al. 2005; Van Ginkel et al. 2012). ${ }^{25}$ Twice a special issue of Tijdschrift voor Hoger Onderwijs (Dutch Journal for Higher Education) was devoted to studies about honors and talent development. In 2010, Van Eijl, Pilot and Wolfensberger edited a Dutch-language handbook on talent development in higher education, mostly taking a practical approach (Van Eijl et al. 2010). A study was also conducted about similar and different approaches and dispositions in American and Dutch honors teaching (Wolfensberger 2012). The functioning of excellence education programs is a central theme in Dutch research on honors (see Wolfensberger and Pilot 2014 ${ }^{26}$ ). One more example is a dissertation focusing on instructional strategies for high-ability students (Scager 2013).

There are also different national networks. SLO (National Expertise Centre Curriculum Development) gathers information about education and talent development. ${ }^{27}$ The Platform Excellence unites different programs focused on stimulating excellence. ${ }^{28}$

One example of research on excellence is the excellence model (YoungWorks 2012). In this model, also published in English, young people's attitudes towards excellence are characterized. The model was developed in a joint cooperation between the Sirius Programme and YoungWorks.

In 2012, National Research Council NWO organized a one-off funding round intended for scientific research focusing on excellence in education (see Segers and Hoogeveen 2012; De Boer et al. 2013 ${ }^{29}$ ). More structurally and specifically focusing on excellence in higher education, research occurs at the Research Centre for Talent Development in Higher Education and Society at the Hanze University of Applied Sciences Groningen. ${ }^{30}$ Marca Wolfensberger and colleagues have made - among other contributions - a typology of honors programs in the Netherlands, identified the reasons why programs were set up and investigated pedagogic ideas which supported them. Goals and effects of these honors programs have been described in

\footnotetext{
${ }^{25}$ See for example the various Dutch researchers contributing to the JNCHC special issue on honors around the globe.

${ }^{26}$ This article provides an overview of Dutch research on talent development in higher education. It is published in a special issue of the journal, specifically focusing on excellence in higher education.

${ }^{27}$ On the website talentstimuleren.nl all initiatives are gathered and professionals can search good practices, working groups in their area, etcetera. This is only available in Dutch.

${ }^{28}$ Platform Excellentie in Dutch, see www.platformexcellentie.nl

${ }^{29}$ More on this topic can be found at http://www.nwo.nl/financiering/onze-financieringsinstrumenten/ magw/programma-voor-onderwijsonderzoek/programma-voor-onderwijsonderzoek---excellentiein-het-primair-voortgezet-en-hoger-onderwijs/programma-voor-onderwijsonderzoek---excellentiein-het-primair-voortgezet-en-hoger-onderwijs.html (Dutch only).

${ }^{30}$ See www.hanze.nl/excellentie (mostly in Dutch).
} 
international literature ${ }^{31}$ Wolfensberger termed the programs 'laboratories for educational innovation' and concluded that spin-off produced 'a strong influence on educational policy in the Netherlands at the primary and secondary as well as university levels' (Wolfensberger et al. 2012a).

\subsection{New Developments}

The education chapter in the coalition agreement of the current government is called 'from good to excellent education' (Rijksoverheid 2012). Since the government took power in late 2012, multiple new plans have been introduced. In March 2014 an extensive plan to make provisions for talented pupils in primary and secondary education was presented. The plan mentions over 20 measures, including the removal of legal barriers for pupils to follow certain subjects at higher levels and the possibility of businesses giving grants to talented pupils. The measures are aimed at all levels of education and top talents are defined as 'the $20 \%$ of pupils that can perform best. At all levels. (...) It is not just about pupils who are very smart and know a lot. It is also about creativity, craftsmanship and competences' (Rijksoverheid 2014a, own translation).

In the field of higher education, the Sirius subsidies ran until the end of 2014 and have not been continued, as the participating institutions have now established their programs. Universities voiced worries about the funding of their programs to the minister (VSNU 2013). However, the majority of the participating universities and universities of applied sciences have committed themselves to continuing the programs for their best students. They have made agreements with the ministry of Education on this matter. In 2013, three research institutes were asked by the ministry to investigate the added value of the Sirius Programme. Results are expected in 2015.

In October 2014, a national summit addressed the future of honors education, under the motto 'The best way to predict the future is to design it' ${ }^{32}$ The summit marked the end of the subsidy era and of Sirius as a main policy instrument. At the same time, the participating Sirius member institutions decided to continue their network permanently.

\subsubsection{Honors Programs per Higher Education Institution}

Many honors programs are present in Dutch higher education institutions. For this book, we have looked at the 14 public research universities and the 37 governmentfunded universities of applied sciences in the Netherlands. We have added one small private university which is a member of the Sirius Programme (Theological

\footnotetext{
${ }^{31}$ For example in the Journal of the NCHC's special issue on 'honors around the globe' in 2012.

${ }^{32}$ See website Sirius Programme for more details.
} 
University of the Reformed Churches Kampen), but we have not looked at other private universities. This leads to an added total of 52 HEIs.

Starting at the public research universities in the Netherlands, we have found that all universities with the exception of the Open University ${ }^{33}$ now have at least one honors program. Most programs are focused at the bachelor level, and they can be divided into mono-disciplinary programs, interdisciplinary programs and multidisciplinary programs, following the distinction made by Wolfensberger et al. (2012a). Monodisciplinary programs are organized per major or department, while interdisciplinary programs bring different departments together or are offered institute-wide. The multidisciplinary programs usually take the form of honors colleges, often offering Liberal Arts and Sciences courses and taking the place of a regular bachelor program. There are eight of these colleges at research universities at the time of writing. ${ }^{34}$

Next to the bachelor programs, there are also a few programs at the master level. This is quite unique, even in an international context. Specifically for these programs, three types of approaches can be distinguished: research-specific, professional, and interdisciplinary (See Van Ginkel et al. 2012).

With regard to the universities of applied sciences, we found that 25 out of the 37 government-funded universities of applied sciences also have honors programs, mostly developed over the last few years. All institutions without honors programs have less than 5,000 students: the 17 largest universities of applied sciences all have honors programs. In all cases, programs have different forms: they can be organized as separate study paths, within the curriculum, co-curricular or extracurricular.

A form of education deserving special mention is the Academische pabo ('academic teacher education'). In the Netherlands, education for primary school teachers is handled in schools called pabo, at the level of universities of applied sciences. In recent years, academic variants of this education program have developed. Such programs often combine bachelor programs in for example pedagogy at research university level with the pabo program at the university of applied sciences level. In many cases, participating students are enrolled at both HEIs and if successful, they receive two diplomas..$^{35}$ These programs are not included in our list, as they are regular education. In some cases, the Academische pabo is presented as a special selective pabo program and it then leads to one diploma, on which the extra work is usually mentioned. We did include these programs in the overview below. ${ }^{36}$

\footnotetext{
${ }^{33}$ The Open University is a special university, focusing on lifelong learning. It is excluded from the table below.

${ }^{34}$ The University Colleges are Utrecht University College, Roosevelt Academy (in Middelburg, connected to Utrecht University), Maastricht University College, Leiden University College, Amsterdam University College, Atlas University College (at Twente University), Erasmus University College (Rotterdam) and University College Groningen (start in September 2014).

${ }^{35}$ In most cases the pabo diploma (bachelor at university of applied sciences) is combined with a bachelor in pedagogic or educational sciences at research university level, both of which can be obtained in a 4-year program. In a program offered by Erasmus University Rotterdam and the Rotterdam University of applied sciences, students can get a pabo diploma and a research university master diploma in pedagogy and education in 5 years.

${ }^{36} \mathrm{~A}$ full list of Academische pabo programs is offered on the website Paboweb: www.paboweb.nl/ themas/14
} 
Participation in all honors programs is growing. In 2012, $3.3 \%$ of all bachelor students participated in an excellence program, and $2.6 \%$ of all master students (Sirius expertcommissie 2014, p. 6). In 2013, the Sirius audit commission visited a selection of 16 programs and found out that student numbers in these programs are growing fast (ibid, p. $7^{37}$ ). Over the last few years many programs which started as experiments, have now established themselves more permanently within their institute. In some programs, universities have started to work explicitly with businesses on solving real-world problems. ${ }^{38}$

Participants in honors programs have also started to organize themselves in honors students' associations. ${ }^{39}$ Most of these are organized per institution, but students are also organizing themselves at the national level through the Honors Community, a platform for honors students in the Netherlands. ${ }^{40} \mathrm{~A}$ first national conference for and by honors students was organized by the Honours Community in 2013, a second one focused on globalization and was held in June 2014. ${ }^{41}$

In addition, a number of honors alumni have started an international network of honors students, called Socrates International Honour Society. Organized in the form of a non-profit foundation, Socrates aims to form a network of honors pupils and students. There are already 'chapters' in eight Dutch student cities and the organization hopes to extend their network to Belgium (Flanders) (Socrates International Honour Society 2014 ${ }^{42}$ ). Recently, Socrates also started to involve secondary schools in their network. Part of their activities are organized in collaboration with (local) businesses or non-profit organizations.

There are also some initiatives for excellent students that are organized outside the higher education system. One example, the Nationale Denktank (National thinktank), provides an annual project in which a group of 20 talented young people cooperate to solve a real-world societal problem. ${ }^{43}$

All of the universities and universities of applied sciences with honors programs are shown on Map 4.1. First, we discuss honors programs at government-supported research universities, before moving on to the honors programs at universities of applied sciences. Because there are so many and different programs, descriptions per HEI will be limited to a general overview and one specific example. Appendix 3 provides a list of links to the institute's general website and if available, the website of the honors program(s).

\footnotetext{
${ }^{37}$ The number of participants in these programs grew over $10 \%$ in universities of applied sciences, over $20 \%$ in university bachelor programs and $18 \%$ in university master programs.

${ }^{38}$ For example Rotterdam University of Applied Sciences in its Innovation Lab and Windesheim in its institute-wide program.

${ }^{39}$ Links to a number of these associations can be found at the Sirius Programme webpage (see key links in Appendix 2).

${ }^{40}$ See www.honourscommunity.nl for more details.

${ }^{41}$ See www.honoursconference.nl

${ }^{42}$ See http://socrateshonours.org/ for more information.

${ }^{43}$ See www.nationale-denktank.nl for more details (Dutch only).
} 


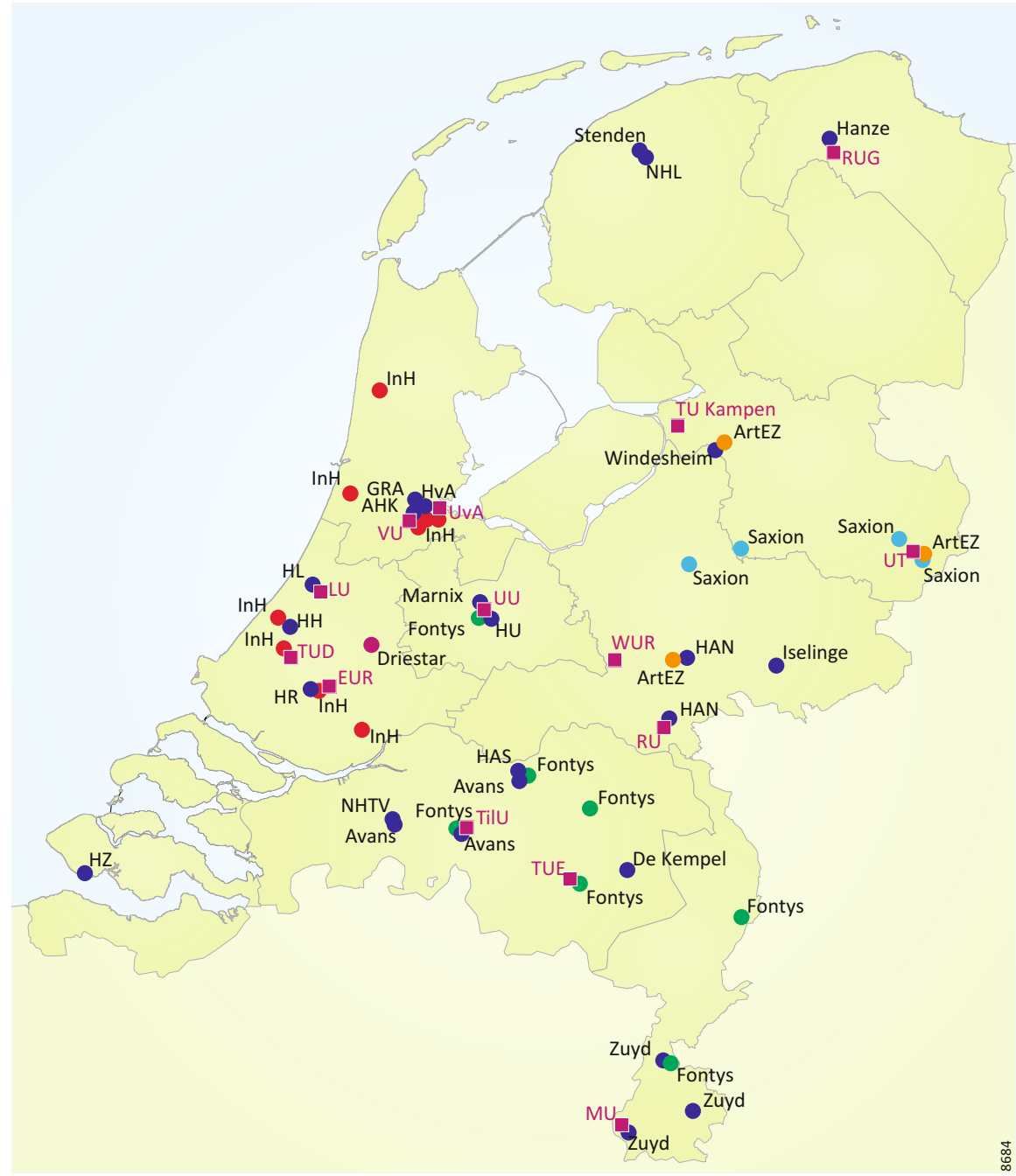

Map 4.1 Dutch higher education institutions with honors programs, 2014

\subsection{Research Universities}

The 14 Dutch government-supported research universities are shown in Table 4.1, ordered by size, measured in student numbers. The programs described below do not have generally applicable features. They can differ in intensity, educational forms, number of ECTS, student numbers and positioning towards the regular program. 
Table 4.1 Honors programs at government-supported research universities in the Netherlands

\begin{tabular}{l|l|l|l|c}
\hline & $\begin{array}{l}\text { Total no. } \\
\text { of students }^{\mathrm{a}}\end{array}$ & $\begin{array}{l}\text { Honors in } \\
\text { bachelor/master } \\
\text { program }\end{array}$ & $\begin{array}{l}\text { Disciplinarity } \\
\text { (disciplinary, } \\
\text { inter, multi) }\end{array}$ & $\begin{array}{l}\text { No. of } \\
\text { honors } \\
\text { students }^{\mathrm{b}}\end{array}$ \\
\hline $\begin{array}{l}\text { University of Amsterdam } \\
\text { (UvA) }\end{array}$ & 31,123 & $\mathrm{~B}$ & $\mathrm{D} / \mathrm{I} / \mathrm{M}$ & 400 \\
\hline Utrecht University (UU) & 30,152 & $\mathrm{~B} / \mathrm{M}$ & $\mathrm{D} / \mathrm{/} / \mathrm{M}$ & 1,500 \\
\hline $\begin{array}{l}\text { University of Groningen } \\
\text { (RUG) }\end{array}$ & 27,169 & $\mathrm{~B} / \mathrm{M}$ & $\mathrm{D} / \mathrm{I} / \mathrm{M}$ & 790 \\
\hline $\begin{array}{l}\text { VU University } \\
\text { Amsterdam (VU) }\end{array}$ & 23,662 & $\mathrm{~B}$ & $\mathrm{D} / \mathrm{I} / \mathrm{M}$ & 400 \\
\hline Leiden University (LU) & 23,007 & $\mathrm{~B} / \mathrm{M}$ & $\mathrm{D} / \mathrm{I} / \mathrm{M}$ & 555 \\
\hline $\begin{array}{l}\text { Erasmus University } \\
\text { Rotterdam (EUR) }\end{array}$ & 22,064 & $\mathrm{~B}$ & $\mathrm{D} / \mathrm{I} / \mathrm{M}$ & 198 \\
\hline $\begin{array}{l}\text { Technical University } \\
\text { Delft (TUD) }\end{array}$ & 19,135 & $\mathrm{~B} / \mathrm{M}$ & $\mathrm{D} / \mathrm{I}$ & 390 \\
\hline $\begin{array}{l}\text { Radboud University } \\
\text { Nijmegen (RU) }\end{array}$ & 18,459 & $\mathrm{~B} / \mathrm{M}$ & $\mathrm{D} / \mathrm{I}$ & 750 \\
\hline $\begin{array}{l}\text { Maastricht University } \\
\text { (MU) }\end{array}$ & 14,894 & $\mathrm{~B} / \mathrm{M}$ & $\mathrm{D} / \mathrm{I} / \mathrm{M}$ & 1,400 \\
\hline Tilburg University (TilU) & 12,589 & $\mathrm{~B}$ & $\mathrm{D} / \mathrm{I}$ & 336 \\
\hline $\begin{array}{l}\text { University of Twente } \\
\text { (UT) }\end{array}$ & 9,314 & $\mathrm{~B} / \mathrm{M}$ & $\mathrm{D} / \mathrm{I} / \mathrm{M}$ & 200 \\
\hline TU/Eindhoven (TUE) & 8,380 & $\mathrm{~B}$ & $\mathrm{D} / \mathrm{I}$ & 57 \\
\hline Wageningen UR (WUR) & 8,299 & $\mathrm{~B}$ & $\mathrm{D} / \mathrm{I}$ & 25 \\
\hline Total & $\mathbf{2 4 8 , 2 4 7}$ & & $\mathbf{7 , 0 0 1}$ \\
\hline
\end{tabular}

a Source: VSNU (2014) (preliminary numbers for 1 October 2013)

${ }^{\mathrm{b}}$ Sources: website Sirius Program or university website (Wageningen)

\subsubsection{University of Amsterdam}

\subsubsection{General}

The University of Amsterdam offers disciplinary and interdisciplinary honors programs. The interdisciplinary programs offered are part of a collaboration between the University of Amsterdam (UvA), the Amsterdam University College (AUC, a residential American-style honors college ${ }^{44}$ ) and VU University Amsterdam (VU). At each university, new modules (courses) start each semester and all honors students can then enroll in one of more than 35 modules offered. Additional courses with a workload of at least half a year will be followed during the bachelor's degree.

\footnotetext{
${ }^{44}$ The Amsterdam University College is a Liberal Arts \& Sciences College, founded by UvA and VU in 2008.
} 
At the end of the bachelor program, honors students who have obtained a minimum grade of 7.5 (on a scale of 1-10) for all regular and extra courses receive an extra certificate with their diploma.

\subsubsection{Specific Example}

Big History illustrates a module in the interdisciplinary program. Students reflect on their own position in space and time, as seen from an unusually broad perspective that covers the history of everything, from the big bang until today. To take part, students are selected for an honors program in their own major study program first. Then students can register, but there are only twenty-five seats per semester and admission is on 'first come, first served' basis.

\subsubsection{Utrecht University}

\subsubsection{General}

Utrecht University has one of the longest traditions in honors education in The Netherlands. It distinguishes honors colleges and honors education. There are four honors colleges, offering full 180 ECTS bachelor programs at honors level. University College Utrecht and University College Roosevelt are both residential colleges, while the College of Pharmaceutical Science and the Utrecht Law College are non-residential. Specific honors education is offered at most faculties of Utrecht University. The students follow at least $25 \%$ of their bachelor courses at honors level, often on top of their regular program. Utrecht University also offers a university-wide interdisciplinary honors program, called Descartes College. In addition, different honors programs in the master phase are also offered. One example is the interdisciplinary Utrecht University Business Course. In this program, thirty students work with entrepreneurs from Utrecht on a pressing business problem. Finally, the Junior College Utrecht runs the U-Talent program for excellent secondary school students.

\subsubsection{Specific Example}

The Descartes College fosters an interdisciplinary honors community for academics from different disciplines. Existing since 2005, talented and motivated students from all over the university can follow interdisciplinary courses, in which they get the opportunity to meet the university's best scientists. In total four courses can be followed. Selection is based on CV, grades and a cover letter, in which students elaborate about their motivation. A selection committee then invites the best applicants for an interview. 


\subsubsection{University of Groningen}

\subsubsection{General}

The University of Groningen offers honors programs for both bachelor and master students, united in the Honours College (in this case not a residential college, but a general term for the program). The bachelor honors program is offered at all nine major departments (which are referred to in the Dutch context as faculties) and is co-curricular. The program has a disciplinary component at a student's 'home faculty' where he follows his major. In this part of the program the students gain in-depth knowledge on their studies. In addition, students also follow part of the program at the 'college', where they gain knowledge in another discipline. The master honors program is also co-curricular and focuses on leadership.

\subsubsection{Specific Example}

The master honors program, founded in 2011, consists of a 1-year program where students get in touch with different aspects of leadership theories and develop leadership skills. The program is in English and consists of four master classes, the leadership lab, a personal development workshop and finally a personal 'masterwork' Admission is based on interviews. Approximately 90 students are in the program. Upon successful completion, students receive an honors certificate with a letter of recommendation of the university's rector magnificus.

\subsubsection{VU University Amsterdam}

\subsubsection{General}

The VU University Amsterdam offers various honors programs. Students complete honors courses within their own department as well as interdepartmental courses for a total of 30 extra credits. The specifics differ per department. The courses in the interdepartmental program are interdisciplinary and are part of a collaboration between VU, UvA and AUC. ${ }^{45}$

\subsubsection{Specific Example}

The honors program of medicine exists as a 4-year research program that can be followed in addition to the regular medicine program. Founded in 2000, students conduct medical scientific research in one of the ten scientific focus-areas of VU. The registration process for this program is lengthy: in the first bachelor year

\footnotetext{
${ }^{45}$ See description University of Amsterdam above for more details on the interdisciplinary program.
} 
students can apply, and 25 students will be conditionally admitted based on academic performance and motivation. These students complete two interdisciplinary honors courses and a short internship at four of the ten focus-areas. After finishing all of that successfully, they may begin their research proposal. The honors students continue their research in the master program. When they finish after nearly 4 years, they offer the results to an international journal. After presenting the results at a final symposium students receive an honors certificate.

\subsubsection{Leiden University}

\subsubsection{General}

At Leiden University, which has one of the longest traditions in honors education in The Netherlands, curious and ambitious students can participate in the Honours College at the bachelor level or the Leiden Leadership Programme at master level. The bachelor Honours College consists of various tracks. Students can choose disciplinary depth or interdisciplinary broadening. They have to choose at least one interdisciplinary project. Students are also a part of the Honours Community. Here, a committee can be joined and participation in various activities is possible. Leiden also has a pre-university college.

\subsubsection{Specific Example}

Founded in 2011, the 1-year Leiden Leadership Programme is offered to master students. Students are challenged to develop themselves into future leaders. This happens in a small learning environment, where direct interaction between teacher, student and fellow students plays a central role. Focus is on developing knowledge and skills in the field of leadership. Skill training courses, seminars and coaching are part of the program. Furthermore, all students work with fellow students on a practical assignment with a partner organization of the university in the private or public sector. Selection is based on a cover letter describing the student's aspirations, CV, a recommendation letter and grades. Each year 55 students take part. When successfully completed, the student receives a certificate.

\subsubsection{Erasmus University Rotterdam}

\subsubsection{General}

Erasmus University Rotterdam offers both disciplinary and interdisciplinary honors programs. The university-wide program is called 'Erasmus Honours Programme'. Here, lecture series in different themes are central. Additionally, students can follow disciplinary honors programs in some departments. The selection requirements of these programs are similar to those of the Erasmus Honours Programme (see below). 


\subsubsection{Specific Example}

Since 2004 the Erasmus University of Rotterdam offers the Erasmus Honours Programme. Participating students are challenged to transcend the borders of their own discipline and look at other disciplines. Students can apply after their first bachelor year. They must have finished all first-year courses with a high average mark and send a letter of motivation and CV. A selection commission chooses 25 participants per year. The program takes three periods of 8 weeks, with a different topic discussed each period. Students submit several assignments per unit. After finishing the program, students receive a special remark on their bachelor diploma, along with a letter of recommendation from the head of the university.

\subsubsection{Technical University Delft}

\subsubsection{General}

Both bachelor and master students can apply for the Honors Program Delft. Successful candidates become members of the Honors community, which consists of online groups and an honors location. Students meet each other and in this way broaden their interests and knowledge. Both the bachelor and master honors program give students the opportunity to design their personal program and take initiative, based on the student's personal interests and opportunities. The students can for example perform a study guided by a professor, write a business plan, perform a task for companies or organize seminars for other students. Application is based on grades and motivation. Upon completion, students receive an honors certificate.

\subsubsection{Radboud University Nijmegen}

\subsubsection{General}

Radboud University has an Honours Academy offering nine disciplinary honors programs in the bachelor phase, which are 'intense, challenging and personally tailored' and three honors programs in the master phase. 150 Master students can participate in the three master honors programs Reflections on Science, Reflections on Professions and Beyond the Frontiers. In addition, there is one interdisciplinary program.

\subsubsection{Specific Example}

One of the bachelor-level disciplinary honors programs is in Social Science, available to 15 students. After a selection process, students participate in a 2-year program which takes about $10 \mathrm{~h}$ of extra study time per week. In the first year 
students follow theoretical and methodological courses. In the second year they undertake individual research and report the results. To apply, students send a cover letter describing their motivation, and their $\mathrm{CV}$ to a selection committee.

\subsubsection{Maastricht University}

\subsubsection{General}

All teaching at Maastricht University is guided by the principle of problem-based learning. In various departments, the best students may follow excellence programs as an extension of their regular courses. These programs focus on academic research competences. Furthermore, there are two university-wide programs: the MarBLE program focused on research-based learning and the PREMIUM program in which interdisciplinary groups of master students work on assignments from the business and government sectors. Finally, University College Maastricht and the Maastricht Science Program are multidisciplinary programs, following the concept of 'Liberal Arts and Sciences'.

\subsubsection{Specific Example}

University College Maastricht is the university's honors Liberal Arts College, founded in 2002. The concept of choice is central. Students are offered a broad range of courses, giving them the opportunity to develop their own talents. The program is very demanding. All teaching is in English and approximately $50 \%$ of students come from abroad. Admission is highly selective and based on grades and an interview. Around 600 students are enrolled.

\subsubsection{Tilburg University}

\subsubsection{General}

Tilburg University offers bachelor students three honors programs. There are disciplinary programs in European studies (European Discourses) and economics (CentER Honors Program). The university-wide Outreaching Honours Program prepares students to 'take responsibility and lead in the society'.

\subsubsection{Specific Example}

In the Outreaching Honors Program, students apply scientific knowledge to social issues and themes, acquire international experience and prepare for social engagement. The program, started in 2010, consists of many components, ranging from 
'Outreaching Labs' to boardroom internships and from an international study trip to support by top coaches. Selection is based on grades, CV, a cover letter describing a student's aspirations, essay and an English proficiency test. The program has a maximum of 50 participating students. Upon successful completion, a certificate is appended to the bachelor degree.

\subsubsection{University of Twente}

\subsubsection{General}

The University of Twente offers both a bachelor and master honors program. The bachelor honors program is interdisciplinary. Students choose between the disciplines Science, Design and Mathematics. Within these disciplines students follow six modules in one and a half years. A main goal of the bachelor program is community building, while the primary goal of the master program focuses on leadership development. In 2013, the university also started the Atlas University College (Academy of Technology and Liberal Arts \& Sciences), a full honors bachelor program.

\subsubsection{Specific Example}

In the Science bachelor honors program students learn about great scientists, everyday scientific situations, write their own research proposal and make a joint final work. The program was founded in 2007 and consists of six modules, including an individual project. Selection is based on study results and motivation. Only 25 students can take part. Upon successful completion, 'Graduated with Honours' becomes inscribed on the diploma.

\subsubsection{TU/Eindhoven}

\subsubsection{General}

The TU/Eindhoven offers an Honors Academy with six excellence tracks for bachelor students, and in the future for master students as well. The Honors Academy started in 2013 and replaces a previous honors program. The overall goal involves preparing students for scientific, societal and personal leadership. Students can dive into their own discipline or explore other disciplines. Admission is based on grades and motivation, assessed in an interview. 


\subsubsection{Specific Example}

An example of a track is 'Empowerment for Health and Wellbeing'. It places students directly within the social context, working with citizens in their everyday life. It is divided in two parts of 15 ECTS credits each. After the first part, the progress and the quality of work of the students is assessed. Students among the top $20 \%$ get a personal invitation, however others can also apply. In the current early stage of development, only six students follow the program; room exists for growth.

\subsubsection{Wageningen UR}

\subsubsection{General}

Wageningen University offers the university-wide interdisciplinary 'Honours Programme'. It starts with an introduction course, after which selection is based on grades and motivation. Per year, 25 students gain admission. They go on an excursion to meet each other, follow different workshops and finally form interdisciplinary research groups. In the following 2 years students conduct research in this group. In addition, the students have the option to use so-called 'honors cards' in their courses. They then follow a more difficult version of this subject. The student can also choose to use the 'honors card' on activities or self-designed projects. During the program students can use a total of four 'honors cards'. Furthermore, the bachelor thesis of the students is enlarged. After finishing the program, students receive a special mention on their bachelor diploma.

\subsubsection{Private University: Theological University of the Reformed Churches Kampen}

The small private Theological University of the Reformed Churches Kampen (TU Kampen) offers a program in theology, which also includes an 'excellence trajectory'. Motivated students who score well can apply for the program. This includes six extra courses of five ECTS each, which can be selected from an offer of 21 courses. Students can start in the last period of their first year or first period of their second year. Upon successful completion, they receive an extra certificate. In early 2014,65 students were enrolled at the university in total. Two bachelor students and two master students followed an excellence trajectory.

\subsection{Universities of Applied Sciences}

A majority of 25 out of 37 government-funded universities of applied sciences, including all the large institutions, now offers some form of honors education. The number has increased in recent years. In 2012, an overview of honors programs at 
universities of applied sciences was made for the national association of universities of applied sciences (Wolfensberger et al. 2012b $\mathrm{b}^{46}$ ). Findings indicated 19 institutions offered a total of 40 excellence programs during 2009/2010.

According to the researchers, "the forty programs could be broadly divided into three categories:

1. Honors programs offered as a complete bachelor program of 240 ECTS. Students enrolled in this category perform all study activities at a higher level. Strikingly, four of five programs in this category are found at teacher training colleges. ${ }^{47}$

2. Excellence programs organized university-wide and offered to students from all majors. Most programs in this category (eight in total) start after the first year of study, are around 30 ECTS and are an addition to the regular study program. Students enrolled in programs in this category follow the regular study program with their peers and have separate classes for the honors course.

3. Excellence programs organized by one faculty [department] for students of a specific major. Programs in this category (27 programs in total) are taken in addition to the regular study program and are generally between 20 and 40 ECTS. Students who successfully completed an honors program, receive an honors supplement or certificate at time of graduation. A number of universities offer a combination of categories discussed above; e.g. an honors program centrally organized for university-wide participation in addition to programs organized at faculty [departmental] level' (ibid, p. 10).

Since publication of this report, a number of new honors programs have been developed at the universities of applied sciences. In early 2014, the Sirius Programme published a study in which a number of participating universities of applied sciences tried to formulate the shared profile of 'excellent professionals' (Sirius Programma 2014a, see also Coppoolse et al. 2013, p. 64).

Table 4.2 depicts the situation at the time of writing. The programs at member institutes of the Sirius Programme and other programs known to the Sirius Programme were first described. The other universities of applied sciences were asked about their honors education offer by e-mail or phone. All institutions except the Thomas More Hogeschool replied. The universities of applied sciences in Table 4.2 are ordered by size (measured in student numbers).

\subsubsection{Amsterdam University of Applied Sciences}

The Amsterdam University of Applied Sciences (Hogeschool van Amsterdam, HvA) puts emphasis on developing programs of excellence with a recognizable, vocational signature. First and second-year students can enter Studium Excellentie, a program where they investigate their talents. Third- and fourth-year students can participate in full honors programs, organized per domain (department). Selection

\footnotetext{
${ }^{46}$ The association was then called HBO Raad, currently it is Vereniging Hogescholen.

${ }^{47}$ See information about Academische pabo in Sect. 4.3.1.
} 
Table 4.2 Honors programs at universities of applied sciences in the Netherlands

\begin{tabular}{|c|c|c|c|c|}
\hline University of applied sciences & $\begin{array}{l}\text { Total number } \\
\text { of students }\end{array}$ & Program & $\begin{array}{l}\text { Disciplinarity } \\
\text { (disciplinary, } \\
\text { inter, multi) }\end{array}$ & $\begin{array}{l}\text { Number of } \\
\text { honors students }\end{array}$ \\
\hline $\begin{array}{l}\text { Amsterdam University of } \\
\text { Applied Sciences (HvA) }^{c}\end{array}$ & 48,027 & Yes & $\mathrm{D} / \mathrm{I}$ & $1,082(2013)$ \\
\hline $\begin{array}{l}\text { Fontys University of Applied } \\
\text { Sciences }\end{array}$ & 42,484 & Yes & $\mathrm{D}$ & $36(2010)$ \\
\hline $\begin{array}{l}\text { HU University of Applied } \\
\text { Sciences Utrecht }(\mathrm{HU})^{\mathrm{c}}\end{array}$ & 36,454 & Yes & $\mathrm{I} / \mathrm{M}$ & $500(2013)$ \\
\hline $\begin{array}{l}\text { Rotterdam University of } \\
\text { Applied Sciences (HR) }^{\mathrm{c}}\end{array}$ & 32,443 & Yes & $\mathrm{I} / \mathrm{M}$ & $\begin{array}{l}1,200-1,500 \\
(2013)\end{array}$ \\
\hline $\begin{array}{l}\text { HAN University of Applied } \\
\text { Sciences }\end{array}$ & 31,921 & Yes & $\mathrm{D} / \mathrm{I}$ & $40(2010)$ \\
\hline $\begin{array}{l}\text { InHolland University } \\
\text { of Applied Sciences }{ }^{\mathrm{c}}\end{array}$ & 30,138 & Yes & $\mathrm{D}$ & $25(2010)$ \\
\hline $\begin{array}{l}\text { Avans University } \\
\text { of Applied Sciences }\end{array}$ & 27,705 & Yes & $\mathrm{D}$ & $20(2010)$ \\
\hline $\begin{array}{l}\text { Hanze University of Applied } \\
\text { Sciences Groningen }^{c}\end{array}$ & 26,223 & Yes & $\mathrm{D} / \mathrm{I} / \mathrm{M}$ & $920(2013)$ \\
\hline $\begin{array}{l}\text { Saxion University of Applied } \\
\text { Sciences }^{c}\end{array}$ & 25,336 & Yes & I & $303(2012 / 2013)$ \\
\hline $\begin{array}{l}\text { The Hague University of } \\
\text { Applied Sciences (HH) }\end{array}$ & 24,783 & Yes & $\mathrm{D}$ & $15(2011)$ \\
\hline $\begin{array}{l}\text { Windesheim University } \\
\text { of Applied Sciences }\end{array}$ & 20,112 & Yes & $\mathrm{I} / \mathrm{M}$ & Unknown \\
\hline $\begin{array}{l}\text { Zuyd University of Applied } \\
\text { Sciences }\end{array}$ & 14,675 & Yes & $\mathrm{D}$ & $24(2010)$ \\
\hline $\begin{array}{l}\text { NHL University of Applied } \\
\text { Sciences }^{\mathrm{c}}\end{array}$ & 11,512 & Yes & $\mathrm{I} / \mathrm{M}$ & $250(2013)$ \\
\hline $\begin{array}{l}\text { Stenden University of Applied } \\
\text { Sciences }\end{array}$ & 10,412 & Yes & $\mathrm{D}$ & $20(2014)$ \\
\hline $\begin{array}{l}\text { University of Applied } \\
\text { Sciences Leiden (HL) }\end{array}$ & 8,794 & Yes & I & Unknown \\
\hline $\begin{array}{l}\text { Breda University of Applied } \\
\text { Sciences (NHTV) }\end{array}$ & 7,171 & Yes & I & $30(2013)$ \\
\hline $\begin{array}{l}\text { HZ University of Applied } \\
\text { Sciences }\end{array}$ & 4,629 & Yes (pilot) & I & $\mathrm{n} / \mathrm{a}$ \\
\hline Christelijke Hogeschool Ede & 4,195 & $\begin{array}{l}\text { No, but due } \\
\text { to start } \\
\text { in } 2015 \\
\end{array}$ & & \\
\hline $\begin{array}{l}\text { VHL University of Applied } \\
\text { Sciences }\end{array}$ & 4,171 & No & & \\
\hline $\begin{array}{l}\text { HKU University of the Arts } \\
\text { Utrecht }\end{array}$ & 3,870 & No & & \\
\hline ArtEZ Institute of the Arts ${ }^{\mathrm{c}}$ & 3,055 & Yes & I & $45(2013)$ \\
\hline $\begin{array}{l}\text { Amsterdam School of the Arts } \\
(\mathrm{AHK})^{\mathrm{c}}\end{array}$ & 2,939 & Yes & $\mathrm{D}$ & $26(2013)$ \\
\hline
\end{tabular}


Table 4.2 (continued)

\begin{tabular}{|c|c|c|c|c|}
\hline University of applied sciences & $\begin{array}{l}\text { Total number } \\
\text { of students }{ }^{\mathrm{a}}\end{array}$ & Program & $\begin{array}{l}\text { Disciplinarity } \\
\text { (disciplinary, } \\
\text { inter, multi) }\end{array}$ & $\begin{array}{l}\text { Number of } \\
\text { honors students }^{\mathrm{b}}\end{array}$ \\
\hline $\begin{array}{l}\text { HAS University of Applied } \\
\text { Sciences }\end{array}$ & 2,591 & Yes & I & 50-90 (2014) \\
\hline $\begin{array}{l}\text { Vilentum University of Applied } \\
\text { Sciences }\end{array}$ & 2,565 & $\begin{array}{l}\text { No, but due } \\
\text { to start } \\
\text { in } 2016\end{array}$ & & \\
\hline Hotelschool The Hague & 1,934 & No & & \\
\hline $\begin{array}{l}\text { VIAA/Gereformeerde } \\
\text { Hogeschool }\end{array}$ & 1,606 & No & & \\
\hline Marnix Academie & 1,552 & Yes & $\mathrm{D}$ & $14(2009)$ \\
\hline $\begin{array}{l}\text { University of the Arts } \\
\text { The Hague }\end{array}$ & 1,542 & $\begin{array}{l}\text { No, but due } \\
\text { to start } \\
\text { in } 2015\end{array}$ & & \\
\hline Driestar Educatief $^{c}$ & 1,321 & Yes & $\mathrm{D}$ & $20(2013)$ \\
\hline Codarts Rotterdam & 972 & No & & \\
\hline Hogeschool iPabo & 935 & $\mathrm{No}^{\mathrm{d}}$ & & \\
\hline $\begin{array}{l}\text { Gerrit Rietveld Academie } \\
\text { (GRA) }\end{array}$ & 894 & Yes & I & $20(2014)$ \\
\hline De Kempel & 757 & Yes & $\mathrm{D}$ & $19(2010)$ \\
\hline Design Academy Eindhoven & 735 & No & & \\
\hline Katholieke Pabo Zwolle & 663 & No & & \\
\hline Thomas More Hogeschool & 506 & - & & \\
\hline Iselinge Hogeschool & 433 & Yes & $\mathrm{D}$ & $36(2014)$ \\
\hline Total & 440,235 & & & \\
\hline
\end{tabular}

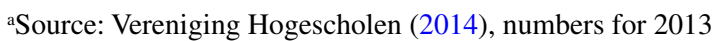

bources: website Sirius Programme, program website or Wolfensberger et al. 2012b, p. 39 (2010 numbers)

'Indicates member Sirius Programme

${ }^{\mathrm{d} A t}$ Hogeschool iPabo, a possible future honors program focusing on excellent mathematics students is in development

is usually based on motivation and portfolio. One interdisciplinary institute-wide honors program exists, Design in Society, where students from different domains work in an innovative way on socially relevant tasks of institutions and businesses in the city.

\subsubsection{Fontys University of Applied Sciences}

Fontys teacher academies offer the PaboPlus program. This program, for primary school teacher students, includes 1 day a week of extra lessons and more focus on research. Around 25 students per year can take part. In communication science, an honors program involves a stay in the USA to conduct research on a topical subject. 


\subsubsection{HU University of Applied Sciences}

The HU University of Applied Sciences (Hogeschool Utrecht, HU) has different honors tracks and works with a star system. Students can earn a total of five stars: as a reflective practitioner, for innovation and dissemination, international perspective, professional drive and leadership qualities. Excellent achievements in all five profile features lead to award of the 'Designation of Excellence' on the bachelor diploma. ${ }^{48}$ The program is flexible, a student can follow a complete program, excel within one course or during an internship, or suggest his or her own activity within the program.

\subsubsection{Rotterdam University of Applied Sciences}

The Rotterdam University of Applied Sciences (Hogeschool Rotterdam, HR) has 'excellence rewarded' as its motto. The honors program is intentionally flexible: themes, expectations and personal characteristics of the students are so varied that programs need to be tailor-made. In general, the program consists of two phases: the 'scouting and recruitment' phase in the first 2 years and the 'research \& innovation' phase in years 3 and 4 . In this second phase, the program focuses on the innovative and multidisciplinary side of the professional. An integral part of all honors programs is taking part in an Innovation Lab in the fourth year of studies. Here the student works in a team of ambitious students to address a topical problem from real companies and institutions in Rotterdam. In addition, a special scholarship is awarded to one of the excellent students, to actually carry out an idea from the honors program experience.

\subsubsection{HAN University of Applied Sciences}

The HAN University of Applied Sciences offers both an institute-wide 'Honours Lab' and a number of disciplinary honors tracks. In the Honours Lab, third- or fourth-year students work in a group for one semester to create an innovative product. ${ }^{49}$ Team development, co creation and passion based learning are key concepts. Selection is based on grades, motivation letter and an interview.

\footnotetext{
${ }^{48} \mathrm{HU}$ has made a flyer about its program available in English. It can be found through: www.international.hu.nl/Study\%20Programmes/Study\%20at\%20HU/Honours-programme.aspx

${ }^{49} \mathrm{~A}$ brochure in English is available at http://www.han.nl/gebied/onderwijs-opleiden/nieuws/ nieuws/het-multidisciplinaire-ho-1/_attachments/honourslab_for_top_students.pdf
} 


\subsubsection{Inholland University of Applied Sciences}

The honors programs at Inholland are organized per discipline, an institution-wide program has been discontinued. Students can register at the end of the second year and every program is broadening and includes a multidisciplinary component. When students finish the program successfully, they receive an honors bachelor degree in addition to their regular diploma.

\subsubsection{Avans University of Applied Sciences}

At Avans teacher education academy, two excellence programs are offered, both called TopClass. The program in behavioral management is a specialization on top of the regular program starting in the third year, while the program in educational innovation runs the full 4 years.

\subsubsection{Hanze University of Applied Sciences Groningen}

The Hanze University of Applied Sciences Groningen (Hanzehogeschool) is a large institution in the north of the Netherlands, with a strong focus on honors and over 50 talent trajectories, including talent programs, minors, specializations, projects and the institute-wide Hanze Honours College. All programs are focused on 'professional excellence'. The institution's target involves having $6 \%$ of all students in these 'talent routes' by late 2015 . Hanze wants honors students and teachers to form an ambitious, stimulating community that is connected to regular students, teachers and the field, and shares its knowledge and experiences.

\subsubsection{Saxion University of Applied Sciences}

Saxion offers honors programs and other 'pathways to excellence'. The honors programs are 3-year broadening programs of around ten ECTS credits per year, in addition to the regular bachelor program. The program challenges the students to become 'Reflective Professionals' with the ability to think transdisciplinary and be bridge builders. Saxion offers nine honors programs in various fields such as entrepreneurship, technology, leadership, care or philosophy. An excellence pathway differs from an honors program: it is an excellence track within the domain of study (the department where the major is taken), focused on deepening knowledge. There is also a special honors program in teacher education at Edith Stein, a school that has recently become part of Saxion. It is called ‘Top Teacher Program'. 


\subsubsection{The Hague University of Applied Sciences}

Since 2010, The Hague University of Applied Sciences (Haagse Hogeschool, HH) offers an honors minor in the study program MER (Management, Economics and Law). This program consists of extra subjects totaling 15 ECTS credits that students can take in their second year. The institution is also developing an Honours College, but this has not yet been realized.

\subsubsection{Windesheim University of Applied Sciences}

Windesheim offers both the Honours College, ${ }^{50}$ a separate program aimed at an international audience, and an interdisciplinary honors program where a group of honors students analyze a topical question, coming from a company, over a relatively short period of time.

Instruction at Windesheim Honours College occurs in English. Students train to become international project managers, specializing in either Public Health or Communication and Media. The students follow an intensive study program and form a learning community, which means they not only study, but also live together. ${ }^{51}$

\subsubsection{Zuyd University of Applied Sciences}

In close cooperation with the Belgian PXL University College, Zuyd offers a 1-year honors program for health care workers from all over the world. Admission criteria include motivation letters and three letters of recommendation. Teaching is entirely in English.

\subsubsection{NHL University of Applied Sciences}

The honors program at NHL is built around the idea of 'community', called NHL Excellent. This is an institute-wide community, in which students work together and with innovative teachers and lecturers to develop their competencies. Students achieve this goal by working on their own projects, completing assignments for external clients, or participation in projects within research groups. At the end of the program, an integral portfolio assessment determines if the student has shown enough excellence to be awarded an extra diploma.

\footnotetext{
${ }^{50}$ See www.windesheimhonourscollege.nl (in English) for more information.

${ }^{51}$ This is an adaptation of a description written by second-year student Elise Eichler, as published in Wolfensberger et al. 2012b, p. 34.
} 


\subsubsection{Stenden University of Applied Sciences}

A broad honors program has been discontinued at Stenden in 2012, but the university of applied sciences still offers two disciplinary modules aimed at excellent students. They are both focused on mathematics and statistics. Motivated students can apply and then follow the modules on top of their regular program. The first module is Mathematics and Statistics for Business and Economics (in English, 10 ECTS), the second is a pre master module in mathematics (in Dutch, 8 ECTS).

\subsubsection{University of Applied Sciences Leiden}

In the Honours program at University of Applied Sciences Leiden students form an honors community and work on projects with socially relevant themes. Students in their second year can apply and selection is based on grades, motivation and an interview. The program is co-curricular, takes 3 years and successful participants receive an extra certificate with their diploma.

\subsubsection{Breda University of Applied Sciences}

Breda University of Applied Sciences (NHTV) started a new honors program in 2013, called 'The Entrepreneurial Journey'. The 2-year English-language study program helps students to develop the skills and knowledge needed to become an entrepreneur. All students can apply for 30 seats in the program and are selected based on motivation and interviews. ${ }^{52}$ In addition, an upgraded graduation track in Strategic Business Management has been developed, granting students an honors bachelor diploma as well as an entry ticket to several business-related MSc programs at a number of research universities.

\subsubsection{HZ University of Applied Sciences}

In September 2014, HZ has started the 'Honours Challenge' as a pilot project. It is an interdisciplinary project aimed at educating reflective professionals who can work across domains. Students can participate from their second year and are selected based on first-year results, a letter in which they describe their motivation and an interview. Participants form an honors community and follow the project on top of their regular bachelor program.

\footnotetext{
${ }^{52} \mathrm{An}$ information leaflet in English can be found at https://insight.nhtv.nl/wp-content/ uploads/2013/09/Information-leaflet-honours-program.pdf
} 


\subsubsection{ArtEZ Institute of the Arts}

ArtEZ is an arts school. Compared to the regular program, the honors program focuses more on theory and research. It is a 2-year program on top of the regular program, with a series of lectures in the first year (some of them on Saturdays) and an individual research project in the second year. Students with good results in the first year can apply with a motivation letter and will then be asked for an interview. The total program involves 30 ECTS credits. Students completing the program earn an extra diploma and a letter of recommendation from the school board.

\subsubsection{Amsterdam School of the Arts}

At Amsterdam School of the Arts (AHK), there is a specific program at the National Ballet Academy. Its Young Bachelor program is ballet at international level. Students can apply to be admitted to this bachelor program while still at secondary school. Contrary to most programs, it is not a separate excellence program, but an existing education program that was already focused on excellence.

\subsubsection{HAS University of Applied Sciences}

At HAS University of Applied Sciences, the honors program consists of interdisciplinary masterclasses for motivated third- and fourth-year students. A masterclass is organized by a lectorate and often based on a topical subject. It consists of six to ten evening meetings with lectures, and a multidisciplinary assignment that students work on in small groups. Students are selected on the basis of motivation. Upon successful participation in one or more masterclasses, they receive a special certificate with their regular diploma. Two to three masterclasses are held per year and on average 25-30 students take part per masterclass.

\subsubsection{Marnix Academie}

The Marnix Academie in Utrecht offers regular teacher education (pabo), but also an academic variant, for which only students with a $v w o$-diploma can be admitted. This full 240 ECTS study program is focused on research and design and includes a pre master. Contrary to academic pabo programs, this program Academische lerarenopleiding (academic teacher education) leads to one diploma and is meant for students who want something different and more challenging than the regular pabo program. 


\subsubsection{Driestar Educatief}

Driestar offers teacher education and has developed an honors program for thirdand fourth-year students. Participants spend an extra day per week at the school where they complete an internship. This day can be spent for example on research. Focus is on 'excellent teachers'.

\subsubsection{Gerrit Rietveld Academie}

The honors program Art and Research is a collaboration between the art school Gerrit Rietveld Academie and the University of Amsterdam. Founded in 2006, it offers extra theoretical input for the art school students, and more creative processes for the university students. A group of around 20 students works on a joint project combining science and art for about 14 months. One of the main ideas is that students contribute to the development of the program's content as it progresses. The program ends with a joint publication and presentation.

\subsubsection{Hogeschool De Kempel}

De Kempel offers teacher education and has developed the Challenge Program for talented students. This is a complete bachelor program combining vocational education with academic education through the Open University. After finishing the 4-year program, students can enter an academic master at Open University, or they can continue teaching and are then primary school teachers 'with a plus'.

\subsubsection{Iselinge}

Iselinge is a small HEI offering teacher education. Since 2009, Iselinge has a selective full 240 ECTS study program called 'Academische PABO' (academic teacher education). Students are selected based on tests, a writing assignment and an interview. They follow a program which includes extra academic modules totaling 40 ECTS, which are offered in cooperation with the Open University. The extra modules are mentioned on the diploma.

The long list of institutes and programs in this chapter shows that honors programs are well-developed in the Dutch context. In all other countries in this study they are rarer, which allowed us some room to discuss the programs in more detail. In the next chapter, we focus on the Netherlands' southern neighbor: Belgium. 
Open Access This chapter is distributed under the terms of the Creative Commons Attribution Noncommercial License, which permits any noncommercial use, distribution, and reproduction in any medium, provided the original author(s) and source are credited.

\section{Literature}

ARWU (Academic Ranking of World Universities). (2013). World university rankings 2013. Retrieved from: www.shanghairanking.com/World-University-Rankings-2013/. 7 Dec 2013.

CBS Statline (Centraal Bureau voor de Statistiek)[Netherlands]. (2014, March). Statline - Different tables. Generated at http://statline.cbs.nl

Coppoolse, R., Van Dijk, T., Ter Woord, R., Weerheijm, R., Vroegindewij, D., Van Eijl, P., \& Pilot, A. (2013). Excellentieprofielen in het hoger beroepsonderwijs. In R. Coppoolse, P. Van Eijl, \& A. Pilot (Eds.), Hoogvliegers - Ontwikkeling naar professionele excellentie (pp. 57-72). Rotterdam: Rotterdam University Press.

De Boer, G. C., Minnaert, A. E. M. G., \& Kamphof, G. (2013). Gifted education in the Netherlands. Journal for the Education of the Gifted, 36(1), 133-150.

Eurydice. (2014). Eurypedia - European Encyclopedia on national education systems. Retrieved from: https://webgate.ec.europa.eu/fpfis/mwikis/eurydice/index.php. Data for different countries gathered November 2013-May 2014. Last checked 22 May 2014.

Hermann, S., Andersen, N. O., Birkving, K., Egebjerg, J., Kingo, L., Hindsholm, S., \& Wilbek, U. (2011). Talentudvikling - evaluering og strategi af Arbejdsgruppen til talentudvikling i uddannelsessystemet. Retrieved from: uvm.dk/service/Publikationer/ /media/UVM/Filer/Udd/ Folke/PDF11/110414_Talentrapport_hele.ashx. 9 Jan 2014.

Kordes, J., Bolsinova, M., Limpens, G., \& Stolwijk, R. (2013). Resultaten PISA-2012-Praktische kennis en vaardigheden van 15-jarigen. Arnhem: CITO. Retrieved from: www.rijksoverheid. nl/documenten-en-publicaties/rapporten/2013/12/03/resultaten-pisa-2012.html. 8 Dec 2013.

Long, A. (2012, fall/winter). Editor's introduction - Special issue "Honors around the globe". JNCHC, 9-15.

Ministerie van Onderwijs, Cultuur en Wetenschap. (2014). Maatgevende scholen II. Excellente scholen in primair, (voortgezet) speciaal en voortgezet onderwijs. Eindverslag 2013 van de Jury Excellente Scholen. Retrieved from: www.rijksoverheid.nl/onderwerpen/predicaatexcellente-scholen/documenten-en-publicaties/rapporten/2014/01/13/maatgevende-scholen-iiexcellente-scholen-in-primair-voortgezet-speciaal-en-voortgezet-onderwijs.html. 7 June 2014.

Persson, R. S., Balogh, L., \& Joswig, H. (2000). Gifted education in Europe: Programs, practices, and current research. In K. A. Heller, F. J. Mönks, R. A. Sternberg, \& R. Subotnik (Eds.), International handbook of giftedness and talent (pp. 703-734). Oxford: Pergamon Press.

Platform Bèta Techniek. (2013). Excellentie in het Voortgezet Onderwijs. Ambitie mag! Denktank excellentiebevordering voortgezet onderwijs. Retrieved from: http://www.platformbetatechniek.nl/media/files/publicaties/Rapport\%20Excellentie\%20A4-WEB.pdf. 28 Feb 2014.

Platform Bèta Techniek. (2014). Passend onderwijs boven de streep. Over excelleren in het primair onderwijs. Denktank excellentiebevordering primair onderwijs. Retrieved from: http://www. platformbetatechniek.nl/media/files/publicaties/Rapport-Excellentie-PO.pdf. 28 Feb 2014.

Rijksoverheid [Netherlands]. (2012). From good to excellent education. Chapter 6 of coalition agreement. Retrieved from: www.government.nl/government/coalition-agreement/vi-fromgood-to-excellent-education. 12 Mar 2014.

Rijksoverheid [Netherlands]. (2014a). Plan van aanpak toptalenten 2014 - 2018. Retrieved from: www.rijksoverheid.nl/onderwerpen/talent-op-school/documenten-en-publicaties/kamerstukken/2014/03/10/plan-van-aanpak-toptalenten-2014-2018.html. 11 Mar 2014.

Rijksoverheid [Netherlands]. (2014b). Centrale loting afgeschaft. Retrieved from: www.rijksoverheid.nl/ministeries/ocw/nieuws/2014/08/30/centrale-loting-afgeschaft.html. 1 Sept 2014. 
Scager, K. (2013). Hitting the high notes: Challenge in teaching honor students. Utrecht University dissertation. Enschede: Ipskamp. http://dspace.library.uu.nl/handle/1874/287573. 15 Jan 2015.

Segers, E., \& Hoogeveen, L. (2012). Programmeringstudie inzake excellentieonderzoek primair, voortgezet en hoger onderwijs. Nijmegen: Radboud Universiteit.

Sirius expertcommissie. (2014). Sirius Programma overall auditrapport 2013. Retrieved from: http://www.siriusprogramma.nl/media/files/publicaties/overall-audit-rapport-v42013.pdf. 28 Feb 2014.

Sirius Programma. (2014a). Hogescholen leiden hun talenten op tot excellente professional. Retrieved from: www.scienceguide.nl/media/1670100/def._siriusboek_excel_prof_v4_.pdf. 28 Feb 2014.

Sirius Programma. (2014b). Sirius program: Promoting excellence in Dutch higher education. Retrieved from: http://www.siriusprogramma.nl/english. 11 Mar 2014.

Socrates International Honour Society. (2014). Over ons - Topprestaties leveren doe je niet alleen. Retrieved from: http://socrateshonours.org/socrates/over-ons/. 12 Mar 2014.

Times Higher Education World University Rankings. (2014). World university rankings 20132014, top-200 (Part). Retrieved from: www.timeshighereducation.co.uk/world-universityrankings/2013-14/world-ranking/range/001-200/order/countrylasc. 28 Jan 2014.

Universiteit Utrecht. (2014). Junior College Utrecht. Retrieved from: www.uu.nl/faculty/science/ EN/vwo/juniorcollege/Pages/default.aspx. 14 Mar 2014.

Van Eijl, P. J., Wientjes, H., Wolfensberger, M. V. C., \& Pilot, A. (2005). Het uitdagen van talent in onderwijs. In Onderwijsraad (Ed.), Onderwijs in thema's (pp. 117-156). Den Haag: Artos.

Van Eijl, P. J., Pilot, A., \& Wolfensberger, M. V. C. (Eds.). (2010). Talent voor morgen. Ontwikkeling van talent in het hoger onderwijs. Groningen: Noordhoff.

Van Ginkel, S., Van Eijl, P., Pilot, A., \& Zubizarreta, J. (2012, fall/winter). Honors in the master's: A new perspective? JNCHC, 265-289.

Vereniging Hogescholen. (2014). Inschrijvingen: Absolute aantallen. Retrieved from: cijfers.hboraad.nl/QvAJAXZfc/opendoc.htm?document=2_Inschrijvingen.qvw\&host=QVS @ cloudbox10232\&anonymous=true. 13 Mar 2014.

VSNU (Vereniging van Universiteiten). (2013, April). Programma's voor excellente studenten staan onder druk. Retrieved from: www.vsnu.nl/files/documenten/Factsheets/14\%20 Factsheet\%20Excellentieprogramma.pdf. 12 Mar 2014.

VSNU (Vereniging van Universiteiten). (2014). Gegevens over instroom, aantal ingeschreven studenten en aantal diploma's. Cijfers februari 2014. Retrieved from: www.vsnu.nl/f_c_studenten_downloads.html. 12 Mar 2014.

Wolfensberger, M. V. C. (2012). Teaching for excellence. Honors pedagogies revealed. Münster: Waxmann.

Wolfensberger, M., \& Pilot, A. (2014). Uitdagingen voor onderzoek naar honoursonderwijs. Tijdschrift voor Hoger Onderwijs, 31/32(1), 124-136.

Wolfensberger, M. V. C., Van Eijl, P., \& Pilot, A. (2012a, fall/winter). Laboratories for educational innovation: Honors programs in the Netherlands. JNCHC, 149-170.

Wolfensberger, M., De Jong, N., \& Drayer, L. (2012b). Leren excelleren. Excellentieprogramma's in het HBO: een overzicht. Resultaten van de landelijke inventarisatie 2009-2010. Retrieved from: http://dspace.library.uu.nl/handle/1874/279130. 28 Feb 2014.

YoungWorks. (2012, February). The excellence model (2nd ed.). Retrieved from: http://www. platformbetatechniek.nl/media/files/publicaties/The\%20Excellence\%20Model.pdf. 8 Dec 2013. 